doi: $10.5559 /$ di.23.3.08

\section{Jayne Metcalfe, Debbie Simpson, Ian Todd, Mike Toyn THINKING THROUGH NEW LITERACIES FOR PRIMARY AND EARLY YEARS Thinking Through Education}

Learning Matters; SAGE, London, 2013., 208 str.

Izdavačka kuća Learning Matters, SAGE objavila je 2013. godine knjigu pod nazivom Thinking Through New Literacies for Primary and Early Years (Promišljanje o novoj pismenosti za početne i rane godine). Knjiga je dio serije naziva Thinking Through Education (Misliti kroz obrazovanje), a istražuje novu pismenost $u$ odnosu na poučavanje i učenje u osnovnoj školi i raspravlja o širokom spektru nove pismenosti i njezinoj ulozi u dječjem razvoju, učenju i životu. Autori pojedinačnih i zajedničkih poglavlja jesu Jayne Metcalfe, Debbie Simpson, Ian Todd i Mike Toyn. Svako poglavlje usredotočeno je na drugačiju vrstu ili aspekt pismenosti i raspravlja o tome kako pismenost može biti najbolje definirana i koje su njezine implikacije na učenje i poučavanje. Knjiga se sastoji od Uvoda (Introduction), strukturiranoga u 9 poglavlja, Literature (References) te Popisa pojmova (Index). Poglavlja započinju pregledom ključnih ishodišta, sadržavaju poveznicu s Učiteljski standardi (Teacher's Standards) i pružaju vježbe razvijanja kritičkoga mišljenja. Napisana je na engleskom jeziku i ima 208 stranica.
Autorica prvoga poglavlja Što je novo o novoj pismenosti? (What's new about new literacies?) Debbie Simpson stavlja naglasak na usvajanje novih definicija o pojmu pismenosti i potiče na razmišljanje o realizaciji pojma pismenosti u propisanim dokumentima, medijima, školi i svakodnevnoj komunikaciji. Autorica objašnjava pismenost kao visoko poželjan uvjet današnjice, a nepismenost kao bolest koju treba istrijebiti. Tri su važne uloge postojanja masovne pismenosti: ekonomska i socijalna dobrobit države te osobni napredak. Pismenost se očituje kao put prema samoaktualizaciji pojedinca. Nadalje, autorica donosi modele pismenosti i izdvaja dva tipa: autonomni i socijalni model (autonomous and social models). Prema autonomnom modelu, osoba je pismena ako je svladala određene vještine, a najvažnija je od njih sposobnost povezivanja izrečenih zvukova (fonema) sa simbolima (grafemima). Prema socijalnom modelu, pismenost je više od samoga kodiranja ili dekodiranja teksta, a mora sadržavati kritičku refleksiju razvijenu kroz socijalizaciju. Po autoričinu mišljenju, postoje razne vrste razgovora ili diskursa, a oni se usvajaju osobnim razvitkom, obrazovanjem, radom i socijalizacijom. Svatko posjeduje primarni način razgovora, ali istodobno može usvojiti mnogo sekundarnih. "Novo" u novoj pismenosti uzima u obzir nove vještine, strategije i prakse ponukane uvođenjem novih tehnologija, a "pismenost" $u$ novoj pismenosti implicira spremnost adaptacije novim tehnologijama kao središnjoj vještini u globaliziranom svijetu.

Tehnološke intervencije u ranoj pismenosti (Technological interventions in early literacy) naslov je drugoga poglavlja, što ga je napisala Jayne Metcalfe. Poglavlje donosi sadašnje i buduće perspektive tehnološke intervencije u podržavanju ranoga čitanja i pisanja sa sociokulturnog stajališta. Autorica ističe da interes djece $u$ upotrebi medija i tehnologija kod kuće ugrađuje socijalno iskustvo koje ima važnu ulogu u razvoju rane pismenosti. Naglasak se stavlja na učitelje, koji trebaju shvatiti važnost 
i brzinu promjene same prirode pismenosti i njezine primjene na poučavanje $\mathrm{u}$ razredu. Pismenost je vezana uz jezik i komunikaciju, ali treba shvatiti da nove tehnologije utječu na stvaranje novih društvenih obrazaca razmjenjivanja i dijeljenja informacije. Djeca danas svoja razmišljanja, ideje i shvaćanja razmjenjuju videom, audiom i tekstualnim porukama, koje se brzo prenose internetom. Autorica ističe potencijal koji može imati rad djece na kreiranju filmova ili videa, odnosno razvoj vještina, poput obogaćivanja i razvoja rječnika. Razvijanje vještine pisanja tipkovnicom također je vrlo poželjno kod djece, a poticanje na igranje online igara razvija određene vještine, poput pisanja po zaslonu s određenom namjerom (Purposeful writing on screen) i igranja uloga (Role play).

Treće poglavlje nosi naslov Verbalna pismenost (Verbal literacy), a autor je Ian Todd. U ovom poglavlju autor stavlja naglasak na verbalnu pismenost, odnosno na vještine potrebne za online čitanje. Autor se pita razlikuju li se naše vještine čitanja digitalnih medija od onih vještina naučenih u tradicionalnim razredima? Nadalje, ističe da online čitanje zahtijeva navigaciju naprijed-natrag na internetskim stranicama, snalaženje u mnoštvu zvukova i slika te da je zahtjevnije nego čitanje tradicionalnih novina, a također traži razvijenu vještinu filtriranja, evaluiranja i kritičkoga analiziranja pročitanoga. Pretraživanje informacija po internetu kompleksna je procedura koja zahtijeva digitalnu pismenost. Danas je često da učenici odustaju od traženja informacija ako im nisu dostupne u kratkom roku, pa se postavlja pitanje: učimo li mi danas djecu da budu spremna na toliku količinu informacija? Zaključno, poglavlje razmatra poziciju ko- ju online čitanje zauzima u svakodnevnom životu, analizira vještine potrebne za online čitanje, kako se ono razlikuje od tradicionalnoga i na koji način pomoći djeci da ih razviju.

U četvrtom poglavlju Pronalaženje stvari - informacijska pismenost (Finding things out - information literacy) Mikea Toyna razmatra se što to znači biti informacijski pismen. Autor pokušava u poglavlju razviti razumijevanje informacijske pismenosti. Konzumenti informacija moraju biti informirani zato da mogu razumjeti pruženu informaciju, odnosno moraju biti informacijski pismeni. Da bi se razumio način filtriranja informacija, mora se shvatiti uloga društva u stvaranju informacija. Autor ističe da su mediji organizirani $u$ svrhu dobivanja moći i profita, stoga informacije kontroliraju oni koji imaju vlast u društvu. Nadalje, navodi tri vrste informacijske pismenosti: funkcionalna informacijska pismenost (functional information literacy), interaktivna informacijska pismenost (interactive information literacy) i kritička informacijska pismenost (critical information literacy). Funkcionalnu informacijsku pismenost definira kao vještinu identificiranja, pronalaženja, evaluiranja i upotrebe informacija; interaktivnu informacijsku pismenost definira kao uključenost učenika u odlučivanje o informacijama potrebnim za dobivanje širega konteksta značenja, dok kritička informacijska pismenost uzima u obzir širi kontekst informacije i stavlja je $\mathrm{u}$ odnos s drugim informacijama. Autor predlaže šest okvira ili načina interpretiranja informacijske pismenosti: sadržajni okvir, kompetencijski okvir, okvir kako se uči, okvir od osobne važnosti, okvir društvenog učinka i relacijski okvir.

Autorica petoga poglavlja, Slušna $i$ oralna pismenost (Aural i oral literacy), Jayne Metcalfe pridonosi razumijevanju uloge digitalne glazbe i zvučnih efekata u svakodnevnom životu djece. Središte interesa ovoga poglavlja jesu načini na koje učitelji mogu pridonijeti dječjem razvoju govornih, slušnih, čitalačkih i pisaćih vještina. 
STR. 535-545

Autorica ističe da danas digitalna tehnologija pruža mogućnost da se glazbi pristupi u svako doba i sa svakoga mjesta, ali i da se glazba, osim slušanja, može i gledati. Sljedeće, predlaže ideje kako učitelji mogu uključiti nove tehnologije $u$ razred: $u$ zeti u obzir glazbenu preferenciju djece, uvesti širok spektar glazbenih stilova $u$ razred, uključiti i glazbu koju djeca slušaju kod kuće, dati djeci priliku da dijele i raspravljaju o svojim glazbenim ukusima itd. Nadalje, Metcalfe navodi strategije koje imaju praktičnu primjenu za učitelje, a dijeli ih na dvije vrste: glazbene aktivnosti (musical activities) i vizualizacijske strategije (visualisation strategies). Autorica definira remiks kao kombiniranje postojećih proizvoda da bi se dobio novi, koji će dati mogućnosti rada i kreativnoga eksperimentiranja. Većina stručnjaka drži da pismenost podrazumijeva pisanje i čitanje, no današnje digitalne generacije rabe $\mathrm{u}$ pravo slike, videa i zvukove da bi izrazili svoje ideje. Poglavlje se nastavlja upoznavanjem s terminom podcasting. Korist od podcastinga u razredu u zadnje su vrijeme prepoznali učitelji, pa je sve češće u upotrebi jer potiče učenje i poučavanje, podržavanje inkluzije, promoviranje individualnog učenja, veće mogućnosti korištenja za učenike s posebnim potrebama, poticanje kreativnosti te zabavan karakter i motivirajući efekt.

U šestom poglavlju Vizualna pismenost (Visual literacy) autor Ian Todd $\mathrm{u}$ središte pozornosti stavlja definiciju vizualne pismenosti te ocjenjuje njezinu važnost $\mathrm{u}$ svijetu gdje dominira digitalna pismenost. Dominacija vizualnih slika putem filmova, fotografija i komercijalnih reklama u svakodnevnom životu postala je informativna i zabavna potreba. Definicija vizualne pismenosti sadrži razne opi- se, poput vještina konstruiranja značenja vizualnih slika, vještina pronalaska značenja u slici, aktivnoga procesa čitanja, interpretiranja i razumijevanja vizualnih medija. Autor se nadalje pita kako vizualna pismenost može pomoći u učenju i pisanju, a odgovor nalazi u faktoru motivacije i zabave. Stoga, kombinacija slika, zvukova i pisanja pomaže u svakodnevnom učenju i poučavanju. Zaključno, slika ima vrlo važnu ulogu u društvu, jer su djeca svakodnevno izložena mnogim raznolikim oblicima i sadržajima. Film i slika imaju veliku moć u motiviranju djece, no nije zanemariva ni činjenica da djeca brže i lakše uče sadržaje koji im se vizualno predoče. Izgubljeni u virtualnom svijet? Djeca $i$ društveni mediji (Lost in cyberspace? Children and social media) naslov je sedmoga poglavlja, a napisale su ga Jayne Metcalfe i Debbie Simpson. Kao polazište autorice uzimaju polet djece prilikom uključivanja u društvene mreže i igranja društvenih igara putem interneta izvan škole. Kroz knjigu se provlači jaz između pismenosti koja se vrednuje u okvirima škole i one koja okružuje djecu u svakodnevnom životu. Po mišljenju autorica, poglavlje ima zadatak skrenuti pažnju na potencijal nove pismenosti u upotrebi društvenih medija, no ističu i važnu ulogu učitelja u vođenju učenika $\mathrm{k}$ ispravnim odlukama u služenju tehnologijom. Sugeriraju postojanje razlika između digitalnih domorodaca (digital natives) i digitalnih imigranata (digital immigrants), a u digitalne imigrante ubrajaju većinu učitelja koji se nisu u djetinjstvu susretali s digitalnim tehnologijama, dok $\mathrm{su}, \mathrm{s}$ druge strane, digitalni domorodci odrasli u okruženju s digitalnom tehnologijom. Osim toga, autorice spominju postojanje dviju vrsta ljudi: one koji svoje vrijeme provode virtualno koristeći se digitalnom tehnologijom kao svakodnevnim izvorom ideja i informacija i one koji to isto traže izvan virtualnoga svijeta.

Nove pismenosti i uključenost (New literacies and inclusion) naslov je osmoga poglavlja, a autori su Debbie Simpson i Mike Toyn. U poglavlju autori razmatraju me- 
đusobnu povezanost novih pismenosti i uključenosti. Nadalje, autori tvrde da se uvođenjem nove pismenosti $u$ razred može podržati i pružiti širok spektar raznih načina izražavanja i prezentiranja, za razliku od tradicionalnoga načina. Upotreba tehnologije može pomoći u lakšem usvajanju jezika, omogućavajući učenicima upotrebu vizualnih vještina kako bi događaje stavili u kontekst razumijevanja. Dječaci i djevojčice okruženi su kulturnim očekivanjima i stereotipovima koji utječu na njihovo ponašanje te prihvaćanje spolne uloge, a može ograničiti njihova očekivanja i uspjeh. Da bi se izbjegao spolni stereotip poučavanja u školi, autori savjetuju da se učitelji moraju praktično evaluirati i međusobno kritički u grupama ocijeniti postojeću praksu i pretpostavke. Na kraju ističu važnost upotrebe moderne tehnologije $\mathrm{u}$ radu $\mathrm{s}$ djecom s posebnim potrebama, točnije disleksijom, kombinacijom teksta, zvuka, glasa i videa.

Zadnje, deveto, poglavlje napisala je Debbie Simpson i naslovila ga Razmatranje pedagogije, etike i zakona u kulturi "remiksa" (Considering pedagogy, ethics and the law in the "remix" culture), a fokus stavlja na istraživanje kulturnih, pedagoških, pravnih i etičnih perspektiva digitalnih i umreženih informacija. Poglavlje učiteljima donosi praktične savjete o načinima upotrebe digitalne tehnologije, s ciljem inspiriranja i razvijanja dječjeg učenja u skladu s postojećim zakonima i oblikovanjem vrijednosti, poput poštovanja, iskrenosti, povjerenja i integriteta. Koristeći se modernom tehnologijom $\mathrm{i}$ alatima $\mathrm{u}$ kreiranju nove stvari, djeca razvijaju vještine i radne navike potrebne $\mathrm{u} 21$. stoljeću. Nadalje, aktivnosti koje se grade na dječjim vještinama i interesima potiču veći angažman i pozitivne ishode poučavanja. Autorica u poglavlju naglašava da djecu treba poučavati da vrednuju tuđi rad, povezujući to s pojmom plagiranja, te ih poticati da se koriste znakom autorskoga prava na svojim radovima te da prije dijeljenja tuđih radova unutar razreda pitaju za dopuštenje. Djeci treba ugraditi etičke i sigurnosne vrijednosti prilikom upotrebe digitalnih tehnologija, jer je uspostavljanje istih, po mišljenju autora, važan segment obrazovanja. Zaključno, učitelji su ti koji moraju biti modeli etičnoga ponašanja svojim učenicima.

Knjiga Promišljanje o novoj pismenosti za početne i rane godine (Thinking Through New Literacies for Primary and Early Years) pisana je jednostavnim stilom, a ključne ideje koje se ističu u poglavljima potkrijepljene su analizama slučaja i vrlo jednostavnim i zanimljivim vježbama razmišljanja. Knjiga kroz devet poglavlja donosi širok spektar razmatranja nove pismenosti u današnjem globaliziranom i digitalnom svijetu. Prezentira koje vještine učenici mogu razviti upotrebom digitalnih tehnologija, a praktičarima sugerira suvisle ideje kako to ostvariti u razredu. Nesumnjivo, knjiga govori o novoj pismenosti, digitalnoj pismenosti, koja nije u razvoju, nego je, dapače, već prisutna među generacijama koje dolaze, a škole kao obrazovne institucije trebaju tu pismenost prihvatiti i uvrstiti u programe.

Ivan Lenard

\section{doi:10.5559/di.23.3.09 \\ Jasminka Ledić, Stjepan Staničić, Marko Turk KOMPETENCIJE ŠKOLSKIH PEDAGOGA}

Filozofski fakultet u Rijeci, Rijeka, 2013., 145 str.

U izdanju Filozofskoga fakulteta u Rijeci te pod okriljem projekta "Sveučilište i vanjsko okruženje u kontekstu europskih integracijskih procesa", 2013. godine objavljena je knjiga "Kompetencije školskih pe- 